\title{
Occult solitary submucosal jejunal metastasis from esophageal
} carcinoma

\author{
Joerg Lindenmann*1, Franz Gollowitsch², Veronika Matzi ${ }^{1}$, \\ Christian Porubsky ${ }^{1}$, Alfred Maier ${ }^{1}$ and Freyja Maria Smolle-Juettner ${ }^{1}$
}

\begin{abstract}
Address: ${ }^{1}$ Department of Thoracic and Hyperbaric Surgery, University Medical School, Auenbruggerplatz 29, Graz, Austria and ${ }^{2}$ Department of Pathology, University Medical School, Auenbruggerplatz 35, Graz, Austria

Email: Joerg Lindenmann* - jo.lindenmann@meduni-graz.at; Franz Gollowitsch - franz.gollowitsch@meduni-graz.at; Veronika Matzi - vero.matzi@meduni-graz.at; Christian Porubsky - christian.porubsky@meduni-graz.at; Alfred Maier - alf.maier@medunigraz.at; Freyja Maria Smolle-Juettner - freyja.smolle@meduni-graz.at

* Corresponding author
\end{abstract}

\section{Published: 16 July 2005}

World Journal of Surgical Oncology 2005, 3:44 doi:10.1/86/1477-7819-3-

44

This article is available from: http://www.wjso.com/content/3///44

(C) 2005 Lindenmann et al; licensee BioMed Central Ltd.

This is an Open Access article distributed under the terms of the Creative Commons Attribution License (http://creativecommons.org/licenses/by/2.0), which permits unrestricted use, distribution, and reproduction in any medium, provided the original work is properly cited.
Received: 27 February 2005

Accepted: 16 July 2005

\begin{abstract}
Background: Metastatic tumors of the intestinal tract from extra-abdominal sites are rare. In esophageal cancer, the liver, lung and the bones are the most common sites of metastases. Metastasis to intestines are very rare.

Case presentation: A 54-year old male was admitted with esophageal squamous cell carcinoma (SCC) associated with dysphagia II-III and weight loss of $20 \mathrm{~kg}$. Preoperative routine staging failed to detect any metastases. A transthoracic esophagectomy and orthotopic gastric pull-up with collar esophago-gastrostomy, associated with 2-field lymphadenectomy was perfromed. During the digital placement of the naso-jejunal feeding catheter a submucosal jejunal nodule with a diameter of $\mathrm{I} \mathrm{cm}$, about $40 \mathrm{~cm}$ distal to the duodeno-jejunal fold was detected which was completely resected by jejunotomy. Histopathology of jejunal nodule showed metastasis from esophageal squamous cell carcinoma.

Conclusion: Because of the extensic esophageal lymphatic system, an occult widespread dissemination of the tumor cells into the abdominal cavity is possible. Additional intraoperative evaluation of the small intestine and the complete abdominal cavity should be performed in every operation of esophageal carcinoma to detect possible occult intraabdominal metastases.
\end{abstract}

\section{Background}

Metastatic tumors of the intestinal tract from extraabdominal sites are rare. In esophageal cancer, the liver, lung and the bones are the most common sites of metastases. Metastases to the small intestine are very rare. We describe the case of a 54-year-old man suffering from esophageal carcinoma, who underwent transthoracic esophagectomy and 2-field lymphadenectomy, the recon- struction was done by orthotopic gastric pull-up. During the operation, a solitary submucosal jejunal metastasis of the esophageal carcinoma was detected and excised.

\section{Case presentation}

A 54-year-old male, alcohol and tobacco user, was admitted with squamous cell carcinoma of the esophagus associated with the clinical symptoms of high-grade dysphagia 
and weight loss of $20 \mathrm{~kg}$. Routine staging was done by computerized tomography (CT)-scan of the thorax and abdomen, ultrasonography, positron emission tomography (PET) scan, esophago-gastro-duodenoscopy and bronchoscopy. Functional evaluation was done by electrocardiogram (ECG), cardiac ultrasonography and spiroergometry.

The CT-scan of the thorax and the mediastinum showed a tumor of the middle third of the esophagus with a suspicion of tumor infiltration of the thoracic aorta and the left main bronchus. However, infiltration of the main bronchus could be excluded by bronchoscopy. Infiltration of the thoracic aorta could also be excluded by MRI-angiography. The CT-scan of the abdomen and the abdominal ultrasound showed no signs of tumor spread. The PETscan demonstrated a pathological tracer uptake at the level of the middle third of the esophagus with no signs of distal metastasis. Esophago-gastro-duodenoscopy showed a tumor stenosis of $7 \mathrm{~cm}$ length, from 30 to $37 \mathrm{~cm}$, and a diameter of $4-6 \mathrm{~mm}$, further there was an intraluminal obstruction about more than $50 \%$ which was additional confirmed by an esophagogram.

Transthoracic esophagectomy and 2-field lymphadenectomy was carried out as reported in literature [1,2]. Intraoperative frozen section showed no residual tumor at the lateral, distal and proximal margins. The mediastinal lymph nodes showed no signs of tumor infiltration. Reconstruction was done by orthotopic gastric pull-up and hand-sewn side to end collar esophago-gastrostomy. In order to perform postoperative early feeding a nasojejunal catheter was introduced and placed distal to the duodeno-jejunal fold.

During the digital placement of the naso-jejunal feeding catheter a submucosal jejunal nodule with a diameter of 1 $\mathrm{cm}$ was detected about $40 \mathrm{~cm}$ distal to the duodeno-jejunal fold. The nodule was completely resected by jejunotomy. Intraoperative frozen section showed a submucosal metastasis of the esophagus. Further evaluation of the small intestine and the complete abdominal cavity showed no signs of metastasis.

Finally histopathological work-up of the specimens confirmed the diagnosis of squamous cell carcinoma of the esophagus (Figure 1) and a solitary submucosal jejunal metastasis. Furthermore, the submucosal jejunal metastasis was associated with local submucosal venous and lymphatic infiltration (Figure 2). In immunhistochemical tests the tumor cells showed reaction to CEA and CK 5-6. The definitive staging was $\mathrm{T}_{3}, \mathrm{~N}_{0}, \mathrm{M}_{1}, \mathrm{~L}_{1}, \mathrm{G}_{3}, \mathrm{R}_{0}$.

The further course of the patient was uneventful and he could be discharged on the $14^{\text {th }}$ postoperative day. As this was stage IV squamous cell carcinoma of the esophagus adjuvant chemotherapy was not offered to the patient [3]. However, a follow-up protocol was initiated with CTscans every 3-month for the first year.

\section{Discussion}

Metastatic tumors of the intestinal tract from extraabdominal sites are rare $[4,5]$. In esophageal cancer, the liver, lung and the bones are the most common sites of metastases. Metastases to the small intestine are very rare [6].

Squamous cell carcinoma of the esophagus is characterized by an extensive lymphatic dissemination via the longitudinal lymphatic system along the esophagus, which drains in to a large number of widespread lymph nodes of the thorax and the abdomen depending on the location of the tumor [2]. Retrograde spread to the cervical, mesenteric and iliac lymph nodes are very unusual, but have been reported in literature $[7,8]$. The intraabdominal region can be reached via the vertebral venous system $[9,10]$. This huge and widespread lymphatic and hematogenous system connecting the esophagus with the intraabdominal region may be sufficient to explain, why this small solitary metastasis of the jejunum was discovered for the first time during the operation and could probably be responsible for this extraordinary bad prognosis in patients with esophageal squamous cell carcinoma caused by the occult widespread dissemination of the tumor cells.

In this case, the operation was absolutely indicated to prevent the patient from further progression of his dysphagia, to avoid the development of a malignant esophagotracheal fistula with its typical complication, mainly bronchopneumonia due to nocturnal aspiration and to avoid the development of an jejunal ileus caused by intraluminal obstruction by that solitary jejunal metastasis. A quite interesting aspect is, why this solitary metastasis could not be discovered by the PET-scan, which showed a pathological tracer uptake at the level of the middle third of the esophagus, further an unspecific tracer uptake due to inflammatory disease in the subhepatic region of the right upper abdomen was seen but there was no suspicion of further distal metastases. The main reason for this failure of the PET-scan could be the high incidence of artifacts caused by many different small intraabdominal focuses of inflammation which make the correct assessment of the abdominal cavity quite difficult.

\section{Conclusion}

Additional intraoperative evaluation of the small intestine and the complete abdominal cavity should be performed in every laparotomy for esophageal carcinoma to detect 


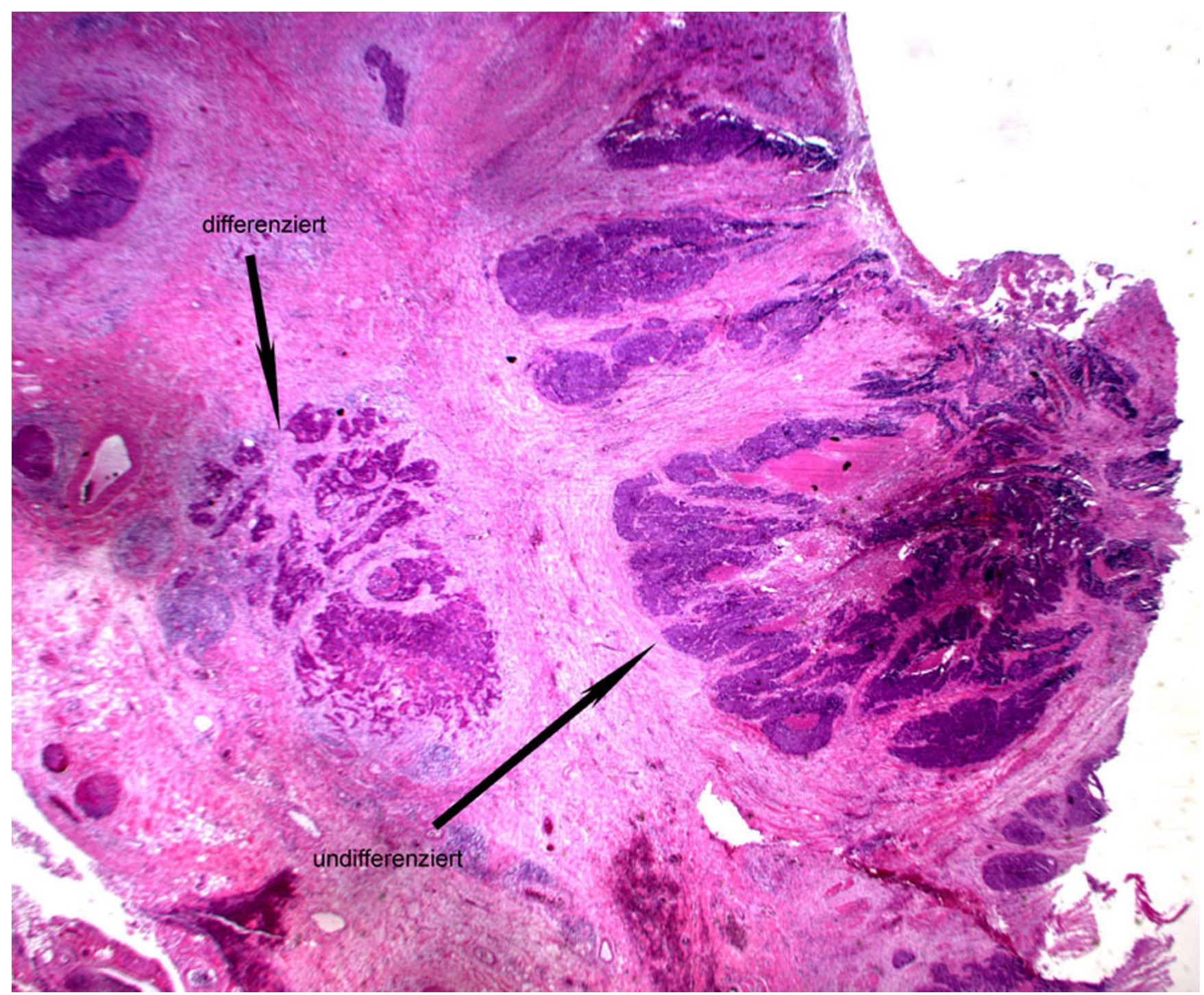

Figure I

Photomicrograph of specimen showing the esophageal SCC (hematoxylin and eosin $\times 25$ ).

possible occult intraabdominal metastases. PET is not sensitive enough to pick small metastasis.

\section{Competing interests}

The author(s) declare that they have no competing interests.

\section{Authors' contributions}

JL: Preparation of draft manuscript, Surgical management, Revision of manuscript and preparation of final manuscript.

VM: Preparation of manuscript, surgical management
AM, Surgical management, Revision of manuscript and preparation of final manuscript

CP, Surgical management

FG: Histopathological work-up, immunhistochemical tests, photomicrograph of specimen.

FMSJ: Revision of manuscript and preparation of final manuscript.

All authors read and approved the final version of the manuscript. 


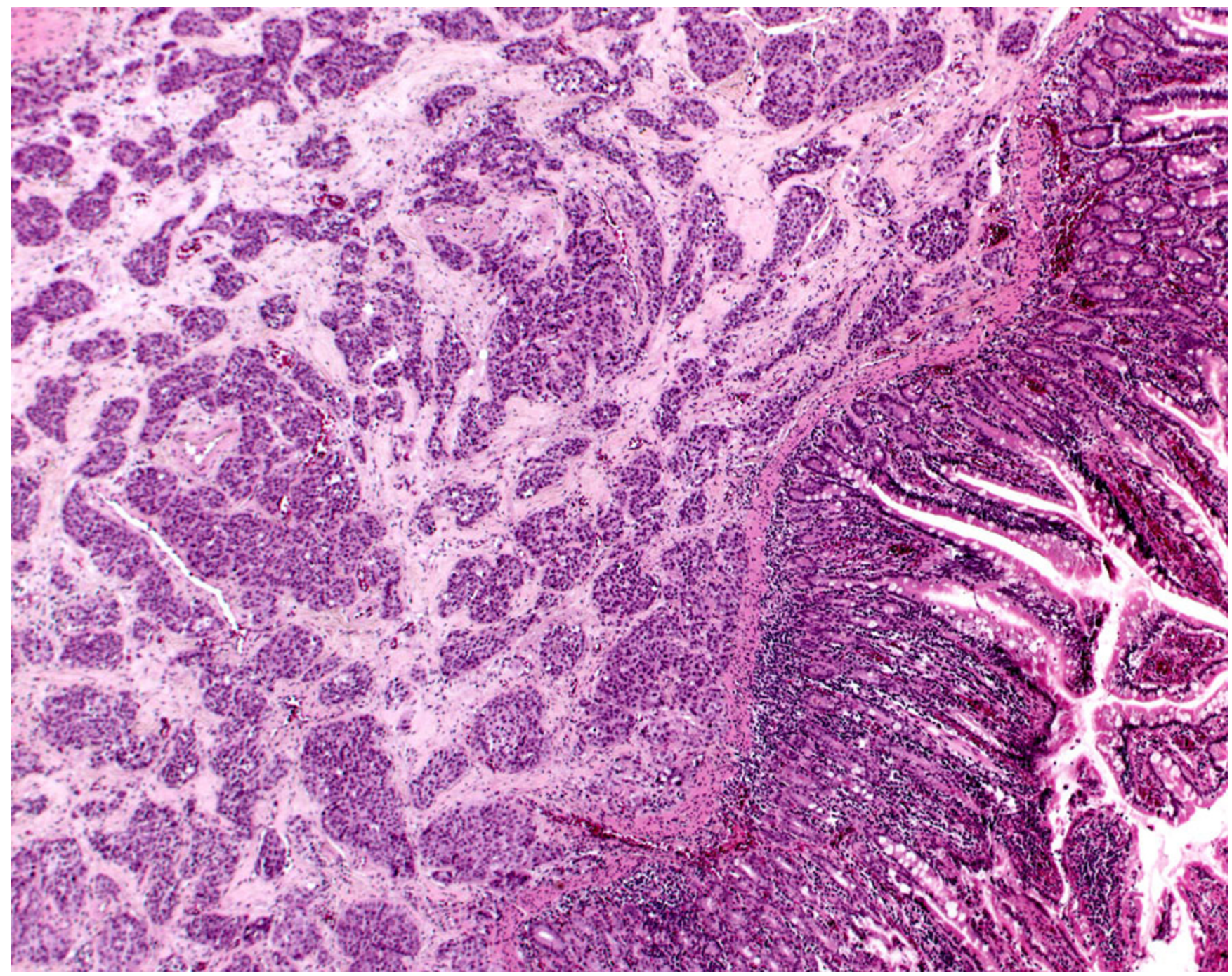

Figure 2

Submucosal jejunal metastasis of the esophageal squamous cell carcinoma (SCC). Photomicrograph of specimen showing the metastasis, associated with local submucosal venous and lymphatic infiltration. Neither the jejunal serosa nor the mucosa are affected by the carcinoma (hematoxylin and eosin $\times 50$ ).

\section{Acknowledgements}

Written consent was taken from the patient for publishing his clinical details and histopathological photomicrographs.

\section{References}

I. Dutkowski P, Kneist W, Sultanow F, Junginger T: Adenocarcinoma of the esophagus: prognostic comparison between transthoracic esophageal resection with expanded 2 -field lymph node dissection and trans-hiatal esophageal dissection with abdominal lymph node excision. Kongressbd Dtsch Ges Chir Kongr 2002, I 19:333-338.

2. Monig SP, Baldus SE, Zirbes TK, Collet PH, Schroder W, Schneider PM, Dienes HP, Holscher AH: Topographical distribution of lymph node metastasis in adenocarcinoma of the gastroesophageal junction. Hepatogastroenterology 2002, 49:419-422.

3. Heroor A, Fujita H, Sueyoshi S, Tanaka T, Toh U, Mine T, Sasahara H, Sudo T, Matono S, Yamana H, Shirouzu K: Adjuvant chemother- apy after radical resection of squamous cell carcinoma in the thoracic esophagus: who benefits? A retrospective study. Dig Surg 2003, 20:229-235. discussion 236-237

4. Caramella E, Bruneton JN, Roux P, Aubanel D, Leconte P: Metastases of the digestive tract. Report of 77 cases and review of the literature. Eur I Radiol I 983, 3:331-338.

5. Wang M, Patel J, Casey TT, Kieffer R, Dunn GD: Metastatic squamous cell carcinoma from the esophagus occurring as small bowel obstruction. South Med ] 1985, 78:884-886.

6. Yamada T, Yagi S, Tatsuzawa Y, Fujioka S, Sato H, Kitagawa S, Nakagawa $M$, Kurumaya $H$ : Small intestinal metastasis from esophageal carcinoma associated with small intestinal obstruction: report of a case. Surg Today 1996, 26:800-802.

7. Thorp MA, Carrie S: Neck abscess: an unusual presentation of a thoracic malignancy. J Laryngol Otol 1998, I I 2:89 |-892.

8. Matthew RM, Singh S, Viswanathan PN, Faith RV: Esophageal carcinoma with spread to mesenteric and iliac Iymph nodes. Indian J Gastroenterol 1999, I 8: I 25. 
9. Kolbusz R, Reyes CV, Hakky M, Gradini R: Asymptomatic esophageal squamous cell carcinoma masquerading as a rare primary panceatic carcinoma. Diagnosis by percutaneous fine needle aspiration. Acta Cytol 1988, 32:399-402.

10. Allen HA, Bush JE: Midesophageal carcinoma metastatic to the stomach: its unusual appearance on an upper gastrointestinal series. South Med J 1983, 76:1049-I05I.

Publish with Bio Med Central and every scientist can read your work free of charge

"BioMed Central will be the most significant development for disseminating the results of biomedical research in our lifetime. " Sir Paul Nurse, Cancer Research UK

Your research papers will be:

- available free of charge to the entire biomedical community

- peer reviewed and published immediately upon acceptance

- cited in PubMed and archived on PubMed Central

- yours - you keep the copyright 